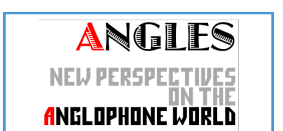

ANELOPHONE WORLI

\section{Angles}

New Perspectives on the Anglophone World

$9 \mid 2019$

Reinventing the Sea

\title{
(Re)inventing a People on the Sea: Instances of Creolization in Amitav Ghosh's Sea of Poppies
}

\section{Ahmed Mulla}

\section{(2) OpenEdition}

1 Journals

\section{Electronic version}

URL: https://journals.openedition.org/angles/1156

DOI: 10.4000/angles. 1156

ISSN: 2274-2042

\section{Publisher}

Société des Anglicistes de l'Enseignement Supérieur

\section{Electronic reference}

Ahmed Mulla, "(Re)inventing a People on the Sea: Instances of Creolization in Amitav Ghosh's Sea of Poppies", Angles [Online], 9 | 2019, Online since 01 November 2019, connection on 06 June 2022. URL: http://journals.openedition.org/angles/1156 ; DOI: https://doi.org/10.4000/angles. 1156

This text was automatically generated on 6 June 2022.

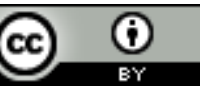

Angles est mise à disposition selon les termes de la Licence Creative Commons Attribution 4.0 International. 


\title{
(Re)inventing a People on the Sea: Instances of Creolization in Amitav Ghosh's Sea of Poppies
}

\author{
Ahmed Mulla
}

1 For a significant amount of time, Creole only sparked the interest of linguists. As early as 1885, Hugo Schuchardt was one of the first philologists to study creole languages and claim that they descended from Western European tongues (Holm 2000: 3). Most of the writings on the subject had long focused on the New World and what is known as Atlantic creoles. However, later works by Carayol and Chaudenson, among others, drew attention to the existence of other creole languages in the former European colonies of the Indian Ocean, notably in La Réunion and Mauritius. However, such studies dealt only with the linguistic aspects of these societies - the sociological and cultural dimensions of creole have only been taken into account more recently. The concept of "creoleness" (créolité) which encompasses these features appeared in the 1980s in the writings of French Caribbean writers Patrick Chamoiseau, Jean Bernabé and Raphaël Confiant; it is a cultural construct whose first foundations were laid at the time of the arrival of the first slaves in these colonies. In the case of Mauritius, the actual settlement started in 1715 (Domingue 1971: 9). In the decades that followed, the island experienced an important "immigration from Africa, Asia, and Europe" (Kuczynski 1948-49: 758). In patterns similar to those observed in the Caribbean, arrivals from different continents contributed to the emergence of a "plural society" (Benedict quoted by Domingue 1971: 7), which in turn furthered the constitution of a creole culture in the Indian Ocean and most specifically in Mauritius.

2 Amitav Ghosh's 2008 novel Sea of Poppies is set in a time frame that comes more than a century later. ${ }^{1}$ Its main action, which consists in an oceanic crossing, takes place in the year 1838, at the exact time when Indian indentured laborers started to be "imported" to Mauritius (Domingue 1971: 10). The island occupies but a very small space in the story, as Amitav Ghosh devotes a large part of his novel to the voyage across the Indian Ocean. The narrative of Sea of Poppies sets in motion a band of desperate individuals 
whose peregrinations and dispersion form the crux of Ghosh's Ibis trilogy, the Ibis being the name of the ship linking different spots of human exploitation around the Indian Ocean.

For people who are unaccustomed to its influence, the marine element becomes an incommensurable presence, both literally and metaphorically. Anupama Arora explains that "[a]lmost all the characters feel the effects of the ocean on their lives in one way or another" (2012: 21). Owing to the fear that takes hold of the indentured travelers in the first days, there exists an undeniable belief that no one will remain intact after the disruptive ocean crossing. Arora adds that "the Indian Ocean is a palimpsest for Ghosh, and in his evocative mapping of this place and time, it becomes a rich archive where he reads layers upon layers of stories of power and violence, exchange, resistance, and survival" (22). As Ghosh's characters belong to different social communities and castes, their interactions are bound to be intensified and renegotiated. Such reconfigurations go hand in hand with loss, dismantlement and the necessity to create a common and new medium to make space for communication and coexistence.

In their pioneering study devoted to the birth and development of creole in the Mascarene islands, Michel Carayol and Robert Chaudenson claim that sugarcane plantations and camps devoted to slaves and indentured workers were the sites where creole was born (Carayol and Chaudenson 1984). Édouard Glissant argues that it is "within the Plantation that the meeting of cultures took shape with the most directly observable acuteness" (1990: 88, my translation). ${ }^{2}$ Without denying this reality, Ghosh's novel suggests that this 'meeting of cultures' which contributed to the emergence of creoleness actually took place during the sea-crossing itself.

This makes us wonder how, even before the actual cohabitation that led to the birth of creole societies on colonial plantations, Ghosh, following the footsteps of Paul Gilroy's idea of the 'Black Atlantic', theorizes the emergence of phenomena of social and cultural creolization at the very time of the ocean crossing. In an approach that replicates Glissant's dismissal of the négritude movement, Gilroy states that the belief in "tradition" and "Afrocentricity" offers no adequate definition of the Black experience today (Gilroy 1993: 191). His theory of the Black Atlantic claims that Black identity can in no way be limited by national paradigms, for it was born through a diasporic process and as such is transnational in essence. The analogies that can be found between slave trade and indenture economy warrant a reading of Amitav Ghosh's Sea of Poppies with the help of Gilroy's theoretical apparatus.

In spite of the dissimilarities between slavery and the system of indenture contracts, research points to the fact that, in the Sea of Poppies, Ghosh purposefully creates strong links between these two types of human exploitation. Ghosh himself states that "the truth is that India was to the late $19^{\text {th }}$ century what Africa was to the $18^{\text {th }}-$ a huge pool of expendable labour" (Ghosh and Chakrabarty 2002: 160). For Jacob Crane, the Ibis that transports indentured workers in Ghosh's novel is in fact a vessel that had served in the slave trade prior to its new assignment. In doing so, "Ghosh locates his novel within a burgeoning transnational Atlanticist discourse" (Crane 2011: 3). Crane also illustrates this idea by showing the importance of Ghosh's interest for slavery, an interest made clear in the allusion to the American abolitionist and former slave Frederick Douglass (5-8). Douglass himself compared slavery and the indenture system: "This Coolie Trade - this cheap labor trade, as now called and carried on - is marked by all the horrible and infernal characteristics of the slave trade" (Douglass 1955: 263). In line with Crane's 
reading, Sneharika Roy argues that "the histories of these oceans intersect through the co-presence aboard the Ibis of Zachary, a product of the Black Atlantic, and the indentured labourers bound for Mauritius, who will become part of the Indian Ocean World" (Roy 2017: 53). This emphasis on intersection leads us to study how patterns of the Kala Pani, which defines the ancestral fear of Ocean crossing shared by many characters in the Sea of Poppies, can be related to the theories of the Black Atlantic.

Indentured workers, also known as "girmitiyas", play a prominent role in Ghosh's narrative. They were hired from many geographical areas of the Indian subcontinent to provide for the economy of sugarcane colonies following the abolition of slavery in 1833 (Crane 2011: 1). Only economic considerations were taken into account while forming groups of girmitiyas and there was no particular concern from organizers of this trade to acknowledge social and caste divisions inherent to Indian society. This explains why this "plantation diaspora", as Omendra Kumar Singh names it (2012: 51), was very diverse (Parekh 1993: 110), especially in terms of caste. My argument is mainly based on this idea of a new diversity and the need to examine how this unaccustomed challenge triggered social and cultural negotiations to conceive a common modus vivendi often used as the defining term for creole societies.

8 The implementation of the indenture system represents the logical outcome of the combined efforts of colonialism and capitalism. As manufacturers of opium, British sahibs imposed poppy as the unique culture in many parts of North-East India (SP 29). ${ }^{3}$ This culture was expensive and ruined farmers (SP 29-30; 94) in such proportions that many impoverished peasants had no choice but to sell their sons and "send them off to Mareech", i.e. the Mauritius Islands (SP 155). Others had to abandon everything and accept to work as indentured labourers abroad. Theirs was a forced exile and Jacob Crane rightly uses the expression "narrative of survival" to define Ghosh's work (Crane 2011: 1). The uprooting occasioned by the ocean crossing instills the trope of separation in the lives of these people who had inhabited the same place from time immemorial. The obligation to go abroad represents a definitive rupture in the lives of many indentured migrants: cut-off from their lands, languages, cultures and families, the identities of these indentured laborers are dislocated, both in terms of time and space. Cultural exchanges are also at work in the ocean crossing phenomenon as advanced by Paul Gilroy in his discourse about the Black Atlantic: "Ships immediately focus attention on the middle passage, [...] on the circulation of ideas and activities, as well as the movement of key cultural and political artifacts" (4). Ghosh's narrative details those phenomena and shows how the sea journey radically transforms the cultural, political and religious foundations of the community of indentured travelers.

Other factors than economic deprivation can also drive individuals to such extremes that they are forced to leave their countries. Deeti, one of the main protagonists of the novel, lives near the small town of Ghazipur, in the area of Bihar (SP 3). When her spouse dies, her brother-in-law and other villagers want her to undergo a sati ceremony, sacrificing herself on her husband's funeral pyre. Deeti is saved at the last moment by Kalua (SP 177-8), a man who lives in a nearby and isolated hamlet and who is called the Chamar-basti due to his inferior caste and to his occupation as a leathermaker (SP 27, 53-4). As transgressors, they have to flee a society they cannot fit in and which condemns them to an inevitable death (SP 224). This hopeless situation leads Deeti and Kalua to give in to Ramsaran-ji's proposal to join the girmitiyas on their way to Mareech (SP 204-5, 225). The only option offered to such desperate people by the 
British colonizers and their Indian agents is to go and seek new beginnings across the ocean.

10 Even before the sea journey, the long march and the travel across the river on the subcontinent constitute a preliminary experience of uprooting. Each halt during the trip undertaken by the girmitiyas is an occasion to be confronted with differences. Though they are not meant to stay permanently in the places they go through, these travelers can only notice what makes people around them perfect strangers. "[T]he women would sit on deck, watching the townsfolk and laughing at the evermoreoutlandish accents in which they spoke" (SP 240). Later on, "the pulwar [a light river boat] crossed an invisible boundary, taking them into a [...] land where the people spoke an incomprehensible tongue" (SP 246). Many migrants like Deeti are, in fact, Bhojpuri speakers (SP 8; 400). "[T]hey could no longer understand what the spectators were saying, for their jeers and taunts were in Bengali" (SP 246). In this scene, Ghosh focuses on the migrants' point of view. The latter become conscious of their inability to cope with the world surrounding them as they do not possess the linguistic codes that could have allowed them to interact and communicate with others. As such, they are in a situation of inferiority and disempowerment. Bernabé, Chamoiseau and Confiant argue that such an acute feeling of "exteriority" and alienation constitutes the first mental step towards creoleness (Bernabé et al. 80, 82).

11 After the journey on the river, the girmitiyas are taken to the newly-built camp where they are supposed to stay until the arrival of the Ibis (SP 281). This is the second transitory space migrants occupy after the pulwar that brought them to Calcutta, and it is again a place of disempowerment. As soon as they reach this camp, an Englishman, who is also a member of the ship's crew, proceeds with their registration. Phonetic misunderstandings lead him to alter their names; a character whose name is Madhu Kalua finds himself renamed "Maddow Colver" (SP 284). The misspelling is never corrected, and decades later this "hallowed nam[e] [...] occurred frequently among [Kalua's] descendants" (SP 284-5). The migrants "are literally translated" (Lauret 2011: 56). There is a kind of translation of names that finds no resistance at the moment it happens, since the people concerned are in no position to reestablish the authenticity of their identities. In a genuine translation, a linguistic object passes from one language to another. Here, names whose validity was obtained from their use, their prevalence and even their signification in the tradition of a country on one side are transcribed into an approximate echo of sounds with neither a linguistic nor a symbolic meaning. What happens with the transformation of names here bears some similarities with the process of creolization. In many cases, creole words are formed through a process of appropriation of the colonizer's language; phonetic similarities can be found but, in the end, a whole new language is created. But the change of names described in the novel is in no way an appropriation as in creole; rather, it is an irreversible alienation. An individual's name is an essential component of his/her identity. It cannot be translated. Any transformation of a name impacts the person's sense of his identity. The dissociation between two denominations of a unique individual is typical of the "cultural schizophrenia" that characterizes the colonial situation (Dahlet 2010: 33, my translation), a neurosis that creoleness endeavors to overcome and heal.

The sea travel imposed and organized by members of the British commercial powers constitutes another manifestation of colonial domination. The deportation not only has psychological consequences on the migrants, it also deprives them of a fundamental 
aspect of their social being. Most of the girmitiyas presented in Sea of Poppies belong to the Hindu community. As such, each is a member of a specific caste, depending on his/ her birth. In an individual's interactions with others, caste is at the forefront as it determines both his/her place and role within society. "For several millennia, caste constituted the core of social and religious life in India" (Singh 2012: 49). One of the worst outcomes that can occur to someone embedded into this system is to lose his/her caste.

13 According to popular beliefs, such an eventuality can happen when one crosses the ocean, that is to say the Kala Pani, or the Black Water (SP 215). The ocean inspires fear in the people of that time. It represents an unknown territory. Even at the psychological level, the sea is a deserted place. The characters of Sea of Poppies are inheritors of a culture and folklore that simply ignore the ocean. In Hindu mythology, the island of Lanka is peopled by "Ravana and his demon-legions" (SP 72). What lies beyond this island is considered as the cause of absolute damnation and whoever crosses the ocean is condemned to an irremediable exclusion from society as he becomes an "outcaste" forever (SP 72). "According to Hindu belief, the traversing of large expanses of water was associated with contamination and cultural defilement as the crossings led to loss of tradition, caste, class and a generally 'purified' ideal of Hinduness" (Mehta 2010: 1). Such tropes of 'purity' and 'contamination' surface often while examining the processes of the formation of creole societies. As far as creole is concerned, a sense of transgression is at work leaving ancestral cultural modes behind to respond to the urgency of the situation and the need to adapt to the diversity of the new social environment.

As the predicament of the poor farmers is so unbearable, they accept to relinquish even the most sacred aspect of their personalities in spite of their fears of becoming "outcastes". The perspective of being sent away across the ocean is perceived as one of the worst forms of punishment, not only in the matters of caste, but also in judicial cases. When Raja Neel Rattan Halder, a respected zemindar, or landowner, is condemned by a British judge in a case of forgery (SP 235), he is sentenced to be "transported to the penal settlement on the Mauritius Islands" (SP 240). He is told by a senior convict that "the sentence you have been given will tear you forever from the ties that bind others" (SP 314). The crossing of the Kala Pani represents a symbolic as well as an actual fall that transcends the hierarchy that exists within the caste system. Migrants and deportees are considered as people who have reached the lowest possible condition, and are thus rejected by those who can afford to stay on firm ground.

This situation of exclusion, of forced exteriority, is the prelude to a heightened phenomenon of creolization. People who migrate through maritime routes lose their castes, that is to say their original positions within society. However, this does not signify they are actually free from the caste system. According to Omendra Kumar Singh, "traditional caste hierarchy [...] continued to exist in some form" even long after settlement (Singh 2012: 49). This is what is implied in the prediction made to Neel Rattan Halder: "When you step on that ship, to go across the Black Water, you and your fellow transportees will become a brotherhood of your own: you will be your own village, your own family, your own caste" (SP 314). The trope of caste remains in the minds of those who do not migrate for they cannot conceive a human society without the presence of this hierarchical system. The difference remains that in this particular situation they envision the creation of a unique caste that regroups all sea migrants 
irrespective of their very different origins. However, the creation of an artificial group of human beings on the Ibis does not imply the advent of a uniform and peaceful society.

At first, a vivid competition is visible at the time of boarding the pulwar that brings the girmitiyas from the countryside to Calcutta. Everyone tries to get the best places aboard the little boat: "the migrants began to disrupt the careful circle of their mats, scuffling and shouting as they fought for space" (SP 370). In the same way, the absence of a real cohesion among the travelers encourages conflicts: "here there were no elders to settle disputes, and no tribes of kinsfolk to hold a man back from going for another's throat" (SP 397). In the indenture trade, former communities are dissolved and each individual becomes a man on his own, with all the chances and possibilities contained in this condition of loneliness.

Even in these early moments of their shared lives, in spite of the disruptive forces that take hold of the company, one can witness the birth of relationships of a different kind, principally based on solidarity. Some eminent characters of the novel make their best to integrate others who seem to belong to the margins. Among the women, Deeti is the one who endeavors to implement this connection when she inquires about her travel companions. Most of them are miserable and desperate women who belong to prejudiced castes as compared to her own. In an unprecedented step towards them, she hides her own identity and adopts her husband's caste. She tells others that she is a "Chamar", that she belongs to the caste of leather-makers (SP 234). The women who travel on the same pulwar are more eager to show her their "sympathy" when she pretends to have lost her daughter than to inquire about her caste: "How does all that matter any more? We're all sisters now, aren't we?" (SP 235).

Paul Gilroy argues that a ship works as "a micro-political system in motion" (1993: 4). Though Gilroy's view is specific to slave ships crossing the Atlantic, it can also apply to vessels transporting indentured workers across the Indian Ocean. Sneharika Roy, for instance, highlights the similarities and "the continuities between these transnational, maritime spaces" (2017: 53). While Roy uses Orlando Patterson's theory of "social death" in relation to the concept of the Kala Pani to define the collapse of the indentured workers' identities prior to and during their sea travel, she also insists on the possibility of counteraction and renewal when she refers to "Ghosh's poetics of karmic rebirth" (52-3). Keeping in mind Gilroy's comment on the political nature of traveling societies or microcosms, one can indeed posit that Ghosh conceives his indentured characters not as passive travelers, but as political actors. In the novelist's view, the former hierarchical organization of this assembly of women into castes is to a certain extent abolished, or rather suspended. And this also concerns other members of the indentured community.

Bhikhu Parekh explains that solidarity was a social necessity for indentured travelers. "The migratory experience [...] generated the spirit of solidarity and weakened the sense of hierarchy. Most of the indentured Hindus belonged to low castes and had every reason to efface all traces of their social origin" (Parekh 1993: 126). Apart from this consideration, it seems likely that the symbolic abolition of caste forms part of Ghosh's poetic agenda in the sense that progressive minds have dismissed this discriminatory system. Within this perspective, renunciation of differentiation aboard the ship comes as a redeeming political act. A parallel can be made with Martin Robison Delany's novel, Blake; or the Huts of America (1859, 1861-62), where a Cuban assumes 
various identities while undertaking the crossing of the Atlantic Ocean from North America to the African continent and then back to the New World again. As in what happens with Ghosh's characters, "Blake imagines escaping that history [of transnational racism] through a vision of black redemption" (McGann 2016: 81). This reminds us of Gilroy's comments on Delany's novel where he emphasizes the birth of a new and common subjectivity: "The version of black solidarity Blake advances is explicitly antiethnic and opposes narrow African-American exceptionalism in the name of a truly pan-African, diaspora sensibility" (Gilroy 1993: 27). If ocean crossing is seen as a cause of "social death", the ignoring of traditional discriminatory practices and the coming together of people from different social backgrounds can represent a survival strategy.

20 Aboard the pulwar, the only woman who is not actually concerned by questions of castes is Paulette Lambert, whom everyone believes to be an Indian going by the name of Putleshwari (SP 355-6). This young woman who was born in India to French parents finds herself among the community of travelers as she has reached a deadlock. She is fleeing sexual harassment and is as desperate as the indentured workers aboard the pulwar. ${ }^{4}$ Paulette explains that she is traveling as a pilgrim and for this precise reason she cannot lose her caste (SP 356). She furthermore proclaims that all those who are traveling together now form a companionship of brothers and sisters. "From now on, and forever afterwards, we will all be ship-siblings - jaház-bhais and jaház-bahens - to each other. There'll be no differences between us" (SP 356). Deeti is stunned by the revolutionary aspect of this assertion and soon advocates the same idea: "In the glow of the moment, she did something she would never have done otherwise: she reached out to take the stranger's hand in her own. Instantly, in emulation of her gesture, every other woman reached out too, to share in this communion of touch" (SP 356). Social relationships are thus redefined and migrants are eager to form a community, if only during the time of their sea travel.

21 A good example of this relatively harmonious understanding takes shape in the celebrations of a wedding. Heeru is a woman who has "lost her firstborn and only child" some time before being abandoned by her husband (SP 242; 431). On the Ibis, she is noticed by "Ecka Nack, the leader of [a] group of hillsmen", who wants "to set up house with [her] when [they] reach Mareech" (SP 430). When Heeru accepts his proposal (SP 441), all the women take part in the wedding preparations. The frenzy is such that everyone agrees to ignore the "inconceiva[bility]" of this alliance between persons of very different backgrounds (SP 431), and, as can be supposed, of different castes. They organize the event on the ship in the shortest time span (SP 448).

On the eve of the wedding, every girmitiya symbolically becomes a member of either the groom's or the bride's family (SP 460). When Heeru and Ecka Nack perform the most important ritual of their wedding, circling a sacred fire seven times, they have to be protected from the dangerous rolling of the ship. Many traveling companions voluntarily "came forward to surround the bride and groom with a webbing of shoulders and arms, holding them upright [...] Soon it was as if the whole dabusa [cabin] were being united in a sacramental circle of matrimony" (ibid. 467). The circular structure symbolizes a society coming together, assembling for a common purpose. In the present case, everyone comes forward in support of a new couple which, in itself, is a symbol of life and hope in the future. As we have pointed out earlier, the girmitiyas 
leave aside their former differences to become a family of sorts, notwithstanding the scale of the phenomena at work.

Omendra Kumar Singh observes that "caste lost much of its hierarchical nature on the ship and later, on the plantation colonies, yet it did not disappear altogether" (Singh 2012: 8). However, Heeru's wedding to Ecka Nack shows that inter-caste alliances were made possible by the coming together of people from different backgrounds. This advent of métissage is only the first in a series of weddings that would take place over centuries. From the moment the caste barrier is transgressed, it is possible to infer that the notion of caste itself cannot remain unaffected. There is something irreversible that happens on the Ibis in terms of religious practices. While the community of girtmitiyas remains attached to rituals associated with a traditional Hindu wedding, it is more tolerant towards the idea of an inter-caste union. The persistence of some rituals and the relinquishing of other practices related to the home country create a culture of compromises and negotiations that can define the notion of 'Coolitude' as theorized by Marina Carter and Khal Torabully. "The chief characteristics of Coolitude are, to sum up, the redefining of 'India', of the relation to India, to other cultures, in the setting of their adoptive homelands. A crosscultural vagabondage (cultural vagrancy) is at its hearts" (Carter and Torabully 2002: 194). If the idea of remaining faithful to one's traditions is still present in the wedding ceremonies, the notion of vagrancy, i.e., the ability to drift away from one's roots, becomes inevitable due to the decentering that takes place along the indenture travel. Véronique Bragard elaborates: "By making the crossing central, Coolitude avoids any essentialism and connection with an idealized Mother India, which is clearly left behind" (Bragard 2008: 15). For simple phenomena, as well as for important rites of passage, the Ibis becomes the stage of an initiatory cultural syncretism and paves the way for a creole society.

Jacob Crane states that ships are "the vehicles of diaspora" (Crane 2011: 2). The isolating power of the sea can only encourage travelers to cooperate in order to go on and even to preserve their cultures in their diversity. The maritime journey between Calcutta and Mauritius is a matter of many weeks. It is enough to make strangers coexist and share a common spirit, as shown in Ghosh's narrative. A similar phenomenon exists among members of the ship's crew. In Sea of Poppies, Ghosh puts the focus on a type of boatmen specifically associated with the Indian Ocean. The lascars, as they are called,

came from places that were far apart, and had nothing in common except the Indian Ocean; among them were Chinese and East Africans, Arabs and Malays, Bengalis and Goans, Tamils and Arakanese. (SP 13)

Yet, the lascars who work on the Ibis are "from one part or another of the [Indian] subcontinent" (SP 188). Though they are "varied" in their cultural and religious traditions, many among them "didn't even know where their origins lay, having been sold off as children to the ghat-serangs who supplied lascars to ocean-going vessels" (SP 188). Their stolen childhood and the lack of a clear consciousness of their cultural belongings make them sea-workers essentially defined by their functions on board. However, this lack of a past that can be precisely mapped is psychologically compensated by each one's endeavors to create his self-portrait. Whenever they are left to themselves, the lascars "sing, drink and pass around a few chillums" (SP 188). In this inebriated state, these men either give an account of who they think they are or assume identities of their own fabrication (SP 188-90). The anecdotes they tell about 
themselves are nevertheless so improbable that they seem to be an adaptation and an appropriation of stories heard from European or Western navigators. There is always an extraordinary dimension attached to their narratives as if each one of them did actually go through a feat of sorts, either as a person of high caste or as someone who has already traveled around the world (SP 189) or even as one who participated in the Battle of Trafalgar (SP 190). The fact remains that all those stories bear a mythological dimension, as if by inventing such narratives these seamen could pride themselves on living a life of substance.

The ocean opens up a void for these sea-workers. They are plucked up from their original places in a more dramatic way than what happens to the girmitiyas because the trauma of separation with the land occurs so early on in their lives that they are unable to have even a vague memory of their pasts. The only strategy left to them is to invent fantasy lives. Moreover, being on the sea constitutes a lifelong experience for the lascars. For this very reason, they invest much of their imaginative efforts in this geographical territory. This seascape is not so much a cultural space in-between their diverse destinations but represents the moving center of their lives. As such, the lascars are open to the various sources of influence they come into contact with.

The ports and countries where they stop have a slight influence on the lascars as evidenced in the case of Serang Ali, the head of the group on the Ibis, who has a good command of Chinese (SP 188). But the lascars' identities actually take shape more frequently aboard the ship. Anupama Arora states that lascars are "the ultimate bordercrossers" (Arora 2012: 27). Zachary Reid, the American carpenter hired on the Ibis (SP 16), gets an idea of the lascar culture through their particular language. "[H]e had to memorize a new shipboard vocabulary, which sounded a bit like English and yet not" (SP 15). In fact, most of the time, the lascars understand the customary commands made in English, whereas most specific orders have to be translated to them by their leader (SP 258). The latter's way of speaking a creolized English influenced by Chinese syntax and intonation "startle[s]" Zachary Reid (SP 16). Besides, the leader's uses of the English idiom are many, even when it comes to give an almost correct English grammatical turn to the rudest Indian swearing expressions (SP 184). ${ }^{5}$

In fact, lascars own a language of their own, the Laskari-that motley tongue, spoken nowhere but on the water, [is] [...] an anarchic medley of Portuguese [...] and Kerala [language] [...] , Arab[ic] [...] and Bengal[i] [...], Malay [...] and Tamil [...], Hindusthani [...] and English [...]" (SP 104)

It is, in short, an idiom to which every speaker and actor contributes, a tongue open to all influences. The term "motley tongue" mentioned in the narrative conveys the idea of a juxtaposition of multiple languages that, though foreign to each other, are sufficiently practised in common to be understood within a defined social group. It is precisely the prolonged proximity between speakers of different languages that has produced creole idioms. However, while established creoles have developed around a dominant colonial tongue, there seems to be no particular hierarchy between the languages that coexist within the Laskari. The tongue created and practised by these mariners of the Indian Ocean can be viewed as one of the most accomplished forms of creole.

Creole is a term that defines a language, a people and a culture. Creoleness, for its part, stands for a socio-cultural process particular to former colonies where different influences merged to form a composite and hybrid culture. Most academic studies tend 
to argue that the mixing of cultures happened on the cotton as well as sugarcane plantations in the colonies. In his novel, Sea of Poppies, Amitav Ghosh seems to implement Paul Gilroy's theory on the "Black Atlantic" in the sense that his characters go through a multi-dimensional mutation during their trip to the colonial island of Mauritius. In the context of indenture migration, sea-crossing can be seen as the main factor of these changes.

Indentured migrants have to overcome their apprehensions of the sea itself and of their prospective lives on the island. They also have to cope with the loss of their castes and traditions and with the need to coexist and cooperate with their diverse companions. The characters of Ghosh's narrative go through life-changing experiences and take revolutionary decisions in the space of a few weeks. They get rid of ancient customs and beliefs and, through gradual, mostly instinctive adjustments, invent a way to live together, which is the main feature of creole societies.

The sea appears to be a transitory and preparatory space that enables indentured migrants to encounter a foreign society that is already creole with a spirit open to compromises, but also with the will to carry on with some of their own cultural traditions. Though at first the ocean symbolizes separation and human exploitation in the name of economic globalization, the revolution operated in Amitav Ghosh's narrative emphasizes the idea that the uprooting of people can also result in the willful and collective establishment of a fraternal mankind transcending all types of partisan loyalties that generally tend to separate a human being from another.

\section{BIBLIOGRAPHY}

Arora, Anupama. “'The Sea is History': Opium, Colonialism, and Migration in Amitav Ghosh's Sea of Poppies.” Ariel 42 (3.4) July-October 2011: 21-42. https://journalhosting.ucalgary.ca/index.php/ ariel/article/view/35321

Benedict, Burton. "Stratification in plural societies." American Anthropologist 64 (6) 1962: 1235-46. doi: 10.1525/aa.1962.64.6.02a00070

Bernabé, Jean, Patrick Chamoiseau, and Raphaël Confiant. Éloge de la Créolité - In Praise of Creoleness. Paris: Gallimard, 1993. Trans. M.B. Taleb Khyar. Baltimore: Johns Hopkins UP, 1990.

Bragard, Véronique. Transoceanic Dialogues: Coolitude in Caribbean and Indian Ocean Literatures. Bruxelles: Presses Interuniversitaires Européennes/Peter Lang, 2008.

Carayol, Michel and Robert Chaudenson. Linguistique et anthropologie des aires créolophones océan Indien et zone américano-caraibe. Université de La Réunion/Université de Provence, 1984.

Carter, Marina and Torabully, Khal. Coolitude: An Anthology of the Indian Labour Diaspora. London: Wimbledon Publishing, 2002.

Crane, Jacob. "Beyond the Cape: Amitav Ghosh, Frederick Douglass and the Limits of the Black Atlantic". Postcolonial Text 6(4) 2011: 1-16. https://www.postcolonial.org/index.php/pct/article/ view/1301 
Dahlet, Patrick. "Déterritorialiser les identités: créolisation, créolité et plurilinguismes." Synergies Brésil (1) 2010: 31-40. https://gerflint.fr/Base/BresilSPECIAL1/dahlet.pdf

Delaney, Martin Robison. Blake; or the Huts of America (1859, 1861-62). Boston: Beacon Press, 2000.

Domingue, Nicole Marie Zuber. Bhojpuri and Creole in Mauritius: A Study of Linguistic Interference and its Consequences in Regard to Synchronic Variation and Language Change. Austin: The University of Texas at Austin, PhD Dissertation in Language, Literature and Linguistics for the degree of Doctor of Philosophy, 1971.

Douglass, Frederick. “The Coolie Trade”, The Life and Writings of Frederick Douglass. Philip S. Foner ed. New York: International Publishers, 1955, vol. IV.

Ghosh, Amitav and Dipesh Chakrabarty. "A Correspondence on Provincializing Europe”. Radical History Review 83 (2002): 145-172. doi: 10.1215/01636545-2002-83-146

Ghosh, Amitav. Sea of Poppies. New Delhi: Penguin/Viking, 2008.

Gilroy, Paul. The Black Atlantic - Modernity and Double Consciousness. London/New York: Verso, 1993. Glissant, Édouard. Poétique de la Relation, Poétique III. Paris: Gallimard 1990.

Holm, John. An Introduction to Pidgins and Creoles. Cambridge: Cambridge UP, 2000.

Kuczinski, Robert René. A Demographic Survey of the British Colonial Empire, Oxford: Oxford UP. 1948-49.

Lauret, Sabine. "Re-Mapping the Indian Ocean in Amitav Ghosh's Sea of Poppies". Commonwealth: Essays and Studies 34(1) Autumn 2011: 55-65.

McGann, Jerome. “Rethinking Delany's Blake”. Callaloo 39 (1) Winter 2016: 80-95. doi: 10.1353/cal. 2016.0024

Mehta, Brinda. "Indianités Francophones : Kala Pani Narratives". L'esprit créateur 50(2) Summer 2010: 1-11. doi: 10.1353/esp.0.0229

Mulla, Ahmed. “Au-delà de l'intersectionnalité : l'ombre et la proie dans Sea of Poppies d'Amitav Ghosh". In Ludivine Royer ed., "Violence and Intersectionality”. Alizés - Revue Angliciste de La Réunion 42 (December 2017): 69-88.

Parekh, Bhikhu. "Some Reflections on the Indian Diaspora". Journal of Contemporary Thought 3 (1993): 105-151.

Roy, Sneharika. "Facets of Freedom: Social Death and Karmic Rebirth in Amitav Ghosh's Sea of Poppies”. Indi@logs 4 (2017): 51-61. doi: 10.5565/rev/indialogs.74

Singh, Omendra Kumar. "Reinventing Caste: Indian Diaspora in Amitav Ghosh's Sea of Poppies". Asiatic 6(1) June 2012: 47-62. https://journals.iium.edu.my/asiatic/index.php/AJELL/article/ view/401

\section{NOTES}

1. All page references to the novel are prefixed SP.

2. “[C'est] dans la Plantation que la rencontre des cultures s'est manifestée avec le plus d'acuité directement observable".

3. Amitav Ghosh, Sea of Poppies (New Delhi: Penguin Viking, 2008). All subsequent references are to this edition. 
4. See, for instance, our article on intersectional violence and what we call "altersectional identity" in Ghosh's Sea of Poppies (Mulla 2017).

5. Sabine Lauret uses the notion of "linguistic migration" to explain the process through which many characters "try to bend foreign words to fit English grammar" (Lauret 2011: 60-1).

\section{ABSTRACTS}

While the East India Company made huge profits from the opium trade between its Indian dominion and China in the 1830s, many people in the colony, Indians and Europeans alike, felt their future was hopeless. Ruined by the compulsory cultivation of opium to the detriment of traditional agriculture that guaranteed self-reliance, or condemned by social prejudice, men and women were left with no other option than to seek a future elsewhere. Forced to share a confined place during a lengthy boat trip to an unknown destination in the Indian Ocean, people of opposed social and cultural backgrounds had to adjust to the unwritten laws of a community formed by chance. The characters of Amitav Ghosh's historical novel, Sea of Poppies, belong to the early waves of indentured workers that traveled throughout the Indian Ocean in the hope of a less arduous future. Notwithstanding their individual fate, Ghosh's narrative shows that the ship constitutes a transitory "society" where each one has to re-negotiate his or her relationship to diversity.

Alors que la Compagnie des Indes Orientales réalisait d'énormes profits grâce au commerce de l'opium entre sa colonie indienne et la Chine dans les années 1830, de nombreux habitants de la colonie, Indiens comme Européens, estimaient que leur avenir était sans espoir. Ruinés par la culture obligatoire de l'opium, établie au détriment d'une agriculture traditionnelle qui permettait l'autosuffisance, ou condamnés par les préjugés sociaux, les hommes et les femmes n'avaient pas d'autre alternative que de chercher un avenir ailleurs. Forcés de partager un endroit confiné pendant un long voyage en bateau vers une destination inconnue dans l'océan Indien, es passagers d'origines sociales et culturelles diverses ont dû s'adapter aux lois implicites d'une communauté formée par le hasard. Les personnages du roman historique d'Amitav Ghosh, Un Océan de pavots, font partie des premières vagues de travailleurs sous contrat qui ont traversé l'océan Indien en quête d'un avenir moins sombre. Indépendamment de leur destinée individuelle, le récit de Ghosh montre comment le navire incarne une « société » transitoire où chacun doit renégocier sa relation à la diversité.

\section{INDEX}

Mots-clés: engagisme, pouvoir, colonisation, migration, diaspora, identité, diversité, hybridité, créolité, mer, Ghosh Amitav

Keywords: indenture system, power, colonization, migration, diaspora, identity, diversity, hybridity, creolization, Ghosh Amitav, sea 


\section{AUTHOR}

\section{AHMED MULLA}

Associate Professor of English at Université de Guyane and a member of the MINEA research center (Migration, Interculturality and Education in the Amazon region), Ahmed Mulla holds a $\mathrm{PhD}$ in postcolonial Anglophone literature from the Université de La Réunion. He gave seminars on new literatures, Indian civilization and postcolonial theory for M.A.-level students within the Faculty of Letters and Human Sciences of the same university. His dissertation dealt with the theme of identity conflicts in the works of Jhumpa Lahiri, and his main research interests have so far concerned questions of gender, identity and diaspora within the works of Amitav Ghosh and Jhumpa Lahiri. Contact: ahmed.al_mulla[at]yahoo.fr 